\title{
"How Do I Stop Checking Things?" Understanding Obsessive-Compulsive Disorder from Neuropsychological Perspective
}

\author{
Ardian Praptomojati ${ }^{1}$ \\ Faculty of Psychology, Universitas Gadjah Mada
}

\begin{abstract}
Obsessive-compulsive disorder (OCD) is the fourth most common mental disorder and WHO classifies it as one of the ten most disabling medical conditions. OCD patients have difficulty in controlling the disturbing thoughts accompanied by ritualistic behaviour performed by the patient as a way to reduce anxiety or fear that leads to distress and significant dysfunction in their everyday life. Studies using neuroimaging techniques indicated a number of abnormal functions in the orbitofrontal cortex and caudate nuclei in OCD patients. Abnormalities in one or more neurotransmitters such as serotonin, glutamate, GABA, and dopamine were also found to be associated with the mechanism of the brain circuitry associated with OCD symptoms. Genetic factors were proven to also contribute considerably to OCD. This article is a literature study on OCD, especially from a neuropsychological perspective highlighting the recent development of various techniques and methods of study.
\end{abstract}

Keywords: abnormality; obsessive-compulsive disorder; neuropsychological perspective

Abstrak. Gangguan obsesif kompulsif merupakan gangguan mental urutan keempat yang paling banyak terjadi di dunia dan digolongkan oleh WHO sebagai salah satu dari sepuluh kondisi medis yang paling melumpuhkan. Penderita gangguan obsesif kompulsif mengalami kesulitan untuk mengendalikan pikiran yang mengganggu disertai adanya perilaku ritualistik yang dilakukan penderita sebagai cara untuk mengurangi kecemasan atau ketakutannya sehingga menimbulkan penderitaan dan disfungsi yang signifikan dalam kehidupannya sehari-hari. Studi menggunakan teknik neuroimaging mengindikasikan adanya abnormalitas fungsi pada orbitofrontal cortex dan caudate nuclei. Abnormalitas pada satu atau lebih neurotransmiter seperti serotonin, glutamat, GABA, dan dopamin, juga ditemukan berkaitan dengan tergganggunya mekanisme kerja sirkuit otak yang berkaitan dengan munculnya gejala gangguan obsesif kompulsif. Faktor genetika juga terbukti memberikan sumbangan yang cukup besar bagi munculnya gangguan obsesif kompulsif. Artikel ini merupakan studi literatur yang mengkaji gangguan obsesif kompulsif dari perspektif neuropsikologi dengan mendasarkan pada perkembangan berbagai teknik dan metode riset terkini.

Kata kunci: abnormalitas; gangguan obsesif kompulsif; perspektif neuropsikologi

\section{Introduction}

A teenager has a habit of checking his or her house door, whether it has been locked

\footnotetext{
${ }^{1}$ Any correspondence regarding this article can be done through: ardian.praptomojati@ugm.ac.id
}

particularly every time he or she is leaving the house. It occurs not merely once or twice but repeatedly and takes much time. He or she also frequently check the stove, lamp, or other electronic devices in the house if they have been in the off 
condition. His or her friends frequently complain about this attitude for being considered disturbing so. If seeing this case, what is being experienced by the teenager? Have you ever experienced or might see such cases?

Principally, each individual has his or her own habits and routines to maintain cleanliness, health, and safety. This can be illustrated through the habit in washing the hands before eating, locking the door before living, switching off the light when leaving the room, or other specific habits such as listening to the music while studying, singing when showering, or reading the book before going to bed (Anxiety and Depression Association of America (ADAA), 2014). However, it is different from the people with obsessivecompulsive disorder (OCD). Most people with such disorder experience unwanted, intrusive, and mostly nonsensical thoughts, images, or urges that the individual tries to eliminate (called obsession). As a result, it will cause them to do some ritualistic and repetitive behaviours (called compulsion) to provide relief (Durand \& Barlow, 2013). Some people realize that their compulsions are illogic but they feel difficult to resist or control them (American Psychiatric Association, 2013).

Obsessive-compulsive disorder is categorized as the fourth most common mental disorder (Kaplan, Sadock, \& Grebb, as cited in Okasha, 2002) and is classified by the WHO as one of the ten most disabling medical conditions (Murray \& Lopez, 1996). American Psychiatric Association (APA) recorded $1,1 \%-1,8 \%$ of people in the world have experienced the obsessive-compulsive disorder. In total, $30 \%$ individuals with the obsessivecompulsive disorder have tic disorder in their lifetime. In the United States, obsessive-compulsive disorder has a mean age at onset of 19.5 years. Around $25 \%$ of cases begin by age 14 years. It has been rare to be found in people above 35 years old. The male has a tendency of earlier onset compared to female. It is approximately $25 \%$ of the male has the onset under ten years old (American Psychiatric Association, 2013). Obsessivecompulsive disorder is recorded to have a lifetime prevalence of approximately $2-3 \%$ (Chamberlain, Blackwell, Fineberg, Robbins, \& Sahakian, 2005; Krzanowska \& Kuleta, 2017). This condition may lead to a significant impairment in everyday life. Based on the measurement of Disability Adjusted Life Year (DALY), a method to measure to what extent a health issue has an effect on human life, the obsessivecompulsive disorder was associated with more disability-adjusted life-years compared to the combination of multiple sclerosis and Parkinson Disease (Hirschtritt, Bloch, \& Mathews, 2017; World Health Organization, 2008).

Obsessive-compulsive disorder without any immediate treatments will grow to be a more severe chronic mental disorder, particularly when the individual is facing stressing situations (American Psychiatric Association, 2013). Individuals with obsessive-compulsive disorder will experience any forms of exceeding thinking and behaviours as a form of his or her anxiety or fear that later on affecting the everyday life function (Dorfman \& Walker, 2007; Leckman, Rauch, \& MataizCols, 2011). This will bring an effect on the low level quality of life for the people with obsessive-compulsive disorder (Jahangard et al., 2018; Remmerswaal, Batelaan, Smit, Oppen, \& Balkom, 2016; Sahoo, Sethy, \& Ram, 2017; Stengler-Wenzke, Kroll, Matschinger, \& Angermeyer, 2006; Vivan, Rodrigues, Wendt, \& Bicca, 2013). 
Individuals with obsessive-compulsive disorder will face prolonged suffering; later on disturbing any domains of life, such as social, family, school and work. This also has an effect on the self-esteem of the individual (Bobes et al., 2007; Hollander et al., 1998; Koran, 2001; Schwartzman et al., 2017). It is not merely impacting the patient; the obsessivecompulsive disorder also brings a significant burden for the family or the caregiver (Grover \& Dutt, 2011; Vikas, Avasthi, \& Sharan, 2011; Wu et al., 2018).

The existing advance of technology has supported the development of studies on the obsessive-compulsive disorder particularly from the neuropsychological approach. As studied from neuropsychological perspective, people with obsessive-compulsive disorder have the abnormalities in the specific area of the brain (Comer, 2010; Kwon, Jang, \& Kang, 2009; Saxena \& Rauch, 2000) and abnormalities of hormone mechanism (Comer, 2010; Pauls, Abramovitch, Rauch, \& Geller, 2014). Other studies also showed that the genetic factors had given a specific contribution for the emergence of obsessive-compulsive disorder (Chamberlain et al., 2005; Mundo, Zanoni, \& Altamura, 2006; Pauls, 2001; Pauls et al., 2014). Through this article, the writer would like to further study and present the obsessive-compulsive disorder based upon the neuropsychological perspective. By further understanding, it is expected that people can be more aware and able to determine the accurate treatment for individuals with obsessive-compulsive disorder. This article also is expected to encourage any other further studies about the obsessive-compulsive disorder particularly based upon the neuropsychological perspective.

\section{Discussion}

Obsessive-Compulsive Disorder based on the Diagnostic and Statistical Manual of Mental Disorders (DSM) 5

American Psychiatric Association (APA) in DSM 5 (2013) explains that the obsessivecompulsive disorder refers to a disorder characterized by the obsession and/or compulsion. Obsessions refers to recurrent and persistent thoughts, urges, or images that are experienced as intrusive and unwanted that cause anxiety or distress. Compulsions are repetitive behaviours or mental acts felt by an individual done as a response to the obsession or in accordance with certain rules that must be rigidly implemented. Most individuals with OCD have both obsessions and compulsions. Compulsions can be in the form of repetitive behaviour (such as hand washing, ordering, or checking) or mental acts (such as praying, counting, repeating words silently). The repetitive behaviour or mental acts frequently has no correlation or unrealistic with anxiety or fear. The patient does it to reduce the stress or anxiety stimulated by the obsession or thought he or she is afraid of. There are no requirements for the minimum duration of the diagnosis execution for the obsessive-compulsive disorder, but the most essential point here is that there has been suffering and dysfunction in everyday life function. The theoretical base of the obsessivecompulsive disorder can be seen more clearly in Figure 1.

The specific content of obsessions and compulsions varies among individuals. DSM 5 (2013) classifies it into a number of forms and theme including: 1) cleanliness in which the individual is obsessed to be afraid of being contaminated by dirt and germs; thus becoming compulsive towards 


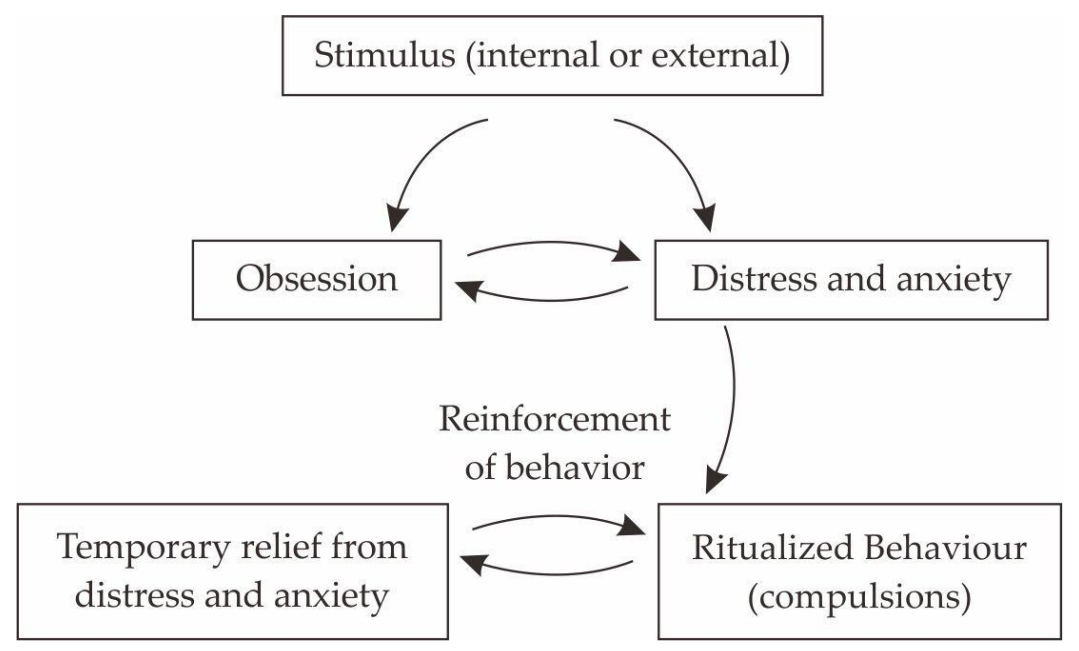

Figure 1. Theoretical base of obsessive-compulsive behaviour

(Pauls et al., 2014)

cleanliness. 2) Symmetry in which the individual is obsessed that all things must be symmetric or on balance thus becoming compulsive towards repetition, order, and counting. 3) Forbidden or taboo thought in which the individual is obsessed towards the thoughts he or she sees as forbidden or taboo such as things related to aggression, sexuality, and religiosity; thus, its compulsion is related to the anxiety/ fear of those things. 4) Harm in which the individual has a fear of harm that might occur with him or her or other people; thus, the form of its compulsion is in the form of checking the related things frequently.

In DSM-IV TR (2000), obsessivecompulsive disorder is categorized in the group of anxiety disorder together with panic disorder, phobia, posttraumatic stress disorder, acute stress disorder, generalized anxiety disorder, and some other forms of anxiety disorder. However, it is different from DSM 5 in which the obsessive-compulsive disorder is categorized into its own category with the title of "Obsessive-Compulsive and
Related Disorders". Obsessive-compulsive disorder is included in this category together with the body dysmorphic disorder, hoarding disorder, trichotillomania (hair-pulling disorder), and excoriation (skin-picking) disorder, and some other forms of obsessivecompulsive and related disorder. This categorization is based upon the similarity of core symptom, i.e. the existence of repetitive thoughts and behaviours and the similarity in phenomenology and neurobiology (Krzanowska \& Kuleta, 2017). WHO also has made a similar adjustment towards the classification of obsessive-compulsive disorder in the International Classification of Diseases eleventh edition (ICD-11) as published in 2018 (Stein et al., 2016).

The decision of APA to remove the obsessive-compulsive disorder from the group of anxiety disorder and to change it as a new category has obtained many criticisms. Three years after DSM- 5 was published, many clinicians and researchers on the obsessive-compulsive disorder argued that the change of the category of 
obsessive-compulsive disorder was unreasonable and lacked support with the strong empirical evidence (Abramowitz \& Jacoby, 2015). Moutaud (2015) stated that the change of the category was based on the consideration that what becomes the fundamental characteristics of obsessivecompulsive disorder principally were the obsession and its compulsion - not its anxiety. Krzanowska and Kuleta (2017) added that the categorization of the disorder is based on the phenomenological and neurobiological tight correlation so that obsessive-compulsive disorder is supposed to be differentiated from the anxiety disorder and other disorder groups. The change of this category also reflects a change of paradigm in seeing the core symptoms of obsessive-compulsive disorder. This new conceptualization is highly related to neuroscience development (Moutaud, 2015). Apart from the controversy in the change of this category, DSM-5 has been a reference and has much helped the professionals in diagnosing the patients.

Neuroimaging and Neuroanatomy on the Obsessive-Compulsive Disorder

The advance of science has led to the understanding of obsessive-compulsive disorder from a neuropsychological approach; moreover with the development of neuroimaging technology. Many studies have shown that obsessive-compulsive disorder is related to the abnormal function in the specific brain area. Many experts are in line that part of the area of the brain tightly related to the obsessivecompulsive disorder is orbitofrontal cortex (located exactly above the eyes) and caudate nuclei (commonly called basal ganglia) (Chamberlain et al., 2005; Comer, 2010; Kwon et al., 2009; Saxena \& Rauch, 2000). This part is a part of the brain circuit changing the sensory information into thought and action (Chamberlain et al., 2005; Parmar \& Sarkar, 2016; Szeszko et al., 2005). Comer (2010) explained that the circuit of the brain starts from the orbitofrontal cortex, an area of the brain that is related to the human primitive impulse such as sex, violence, and other primitive impulses. The impulse then would move on the caudate nuclei that act as a filter that only sends the strongest impulse to the thalamus. When the impulse reaches thalamus, the individual is stimulated to think further about them and triggers to act. To the individual with obsessive-compulsive disorder, the area of orbitofrontal cortex and the caudate nuclei become too active; as a consequence, it then arises the turmoil between thoughts and troublesome actions. Figure 2 shows the structure of the human brain.

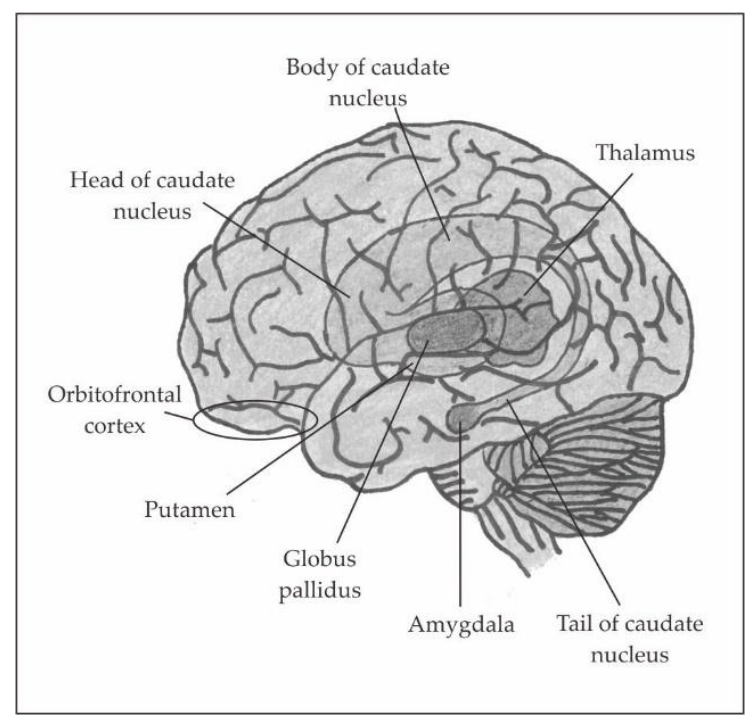

Figure 2. Human brain structure

Research in neuropsychology has been developed rapidly over the past few decades. Some experts even use a number of different techniques to find the accurate evidence. One of the techniques used is Positron Emission Tomography (PET) scan - an imaging technique resulting in the 
three-dimensional image from the functional process in the body using radiotracers such as fludeoxyglucose. The concentration of tracer images will show the metabolism activities of brain tissues (Parmar \& Sarkar, 2016). The study using fluorodopa-PET has been done by a number of researchers and showed that there was an increase metabolism in the orbitofrontal cortex, caudate nucleus, anterior cingulate cortex, lenticular nucleus and thalamus, and parietal cortex in an individual with the obsessivecompulsive disorder (Parmar \& Sarkar, 2016). The symptom of obsessivecompulsive disorder also comes out due to the hyperactivities along with specific, frontal-subcortical circuits connecting the orbitofrontal cortex, ventromedial caudate, globus pallidus, and medial dorsal nucleus of the thalamus (Fineberg, Saxena, Zohar, \& Craig, 2011).

Another technique used in research is Single Photon Emission Computed Tomography (SPECT), an imaging test of nuclear that is able to see how the blood flows to the tissues and organ of the body. Lucey and colleagues (1997) figured out that an individual with obsessivecompulsive disorder has the abnormality on regional cerebral blood flow (rCBF). Compared to the average individual or even with the individual with panic disorder, the individual with obsessivecompulsive disorder has lower rCBF (particular the right caudate). Regional cerebral blood flow (rCBF) is defined as the amount of blood flow to a specific area of the brain at a particular time. Cerebral blood flow becomes a vital part and tightly managed by the body as it functions to fulfil the metabolic needs of the brain. Too much blood flow can damage the brain tissues due to the increased intracranial pressure. Conversely, too little blood can also cause ischemia (Sharma, 2011).

Magnetic Resonance Spectroscopy (MRS) is a technique that can make the research to see the chemical elements of the brain without a need for exogenous tracers or the exposure of ion radiation. This technique is able to be used to see the information about the function of the neuron (Kwon et al., 2009). Through MRS, Ebert and colleagues (1997) found that the level of N-acetyl-aspartate (NAA) is relatively lower in the right striatum of the individual with the obsessive-compulsive disorder. NAA is the second most abundant molecules (after glutamate) in the nervous system which is synthesized by synaptosomal mitochondria from aspartate and acetyl-coenzyme $\mathrm{A}$. The level of NAA frequently is related to neuropsychiatric disorders and brain pathologies (Bhakoo, 2012). Bartha and the colleagues (1998) in their study, also found that the individual with obsessivecompulsive disorder has a lower level of NAA in the left corpus striatum compared to the average individual. Based on those two studies, it can be concluded that there is an abnormality of NAA level to the individual with obsessive-compulsive disorder.

Other studies used CT scan X-ray and showed that the volume of the caudate nucleus in the patient with the obsessivecompulsive disorder was significantly lower than the average individual. Furthermore, there was no difference found in volume in the structure of lenticular nuclei, third ventricle, and lateral ventricle when compared to average individual (Luxenberg et al., 1988). A study using MRI also showed abnormality in the caudate nucleus to the patient with obsessive-compulsive disorder. The patient with obsessive- 
compulsive disorder has a lower volume of the caudate nucleus compared to the average individual. Meanwhile, based upon MRI, there were no differences in size in the prefrontal cortex or in volume in lateral or third ventricles (Robinson et al., 1995).

Near-infrared spectroscopy (NIRS) is the neuroimaging technique that has been widely used to the cases of psychiatric disorder for having a better security level, not needing the bigger devices, and having lower cost if compared to other technique. NIRS has almost ten times higher spatial resolution and can be used repeatedly within a long-time period (Parmar \& Sarkar, 2016). Study in adult patient with obsessive-compulsive disorder shows that there is a change of oxy-Hb in the prefrontal cortex when given the Stroop colour-word task. This finding indicates that prefrontal dysfunction is associated with adult OCD (Okada, Ota, Iida, Kishimoto, \& Kishimoto, 2013). A similar finding also was found in child patient. The area of prefrontal cortex plays an important role in the pathophysiology of OCD. Measured by NIRS, children with obsessive-compulsive disorder have reduced prefrontal hemodynamic response (Ota et al., 2013).

The next technique used to study the brain condition is Magnetoencephalography (MEG), a tool of neuroimaging with the high temporal and spatial resolution that is capable of examining the spontaneous brain activity. This technique is capable of showing the brain activities more directly if compared to SPECT or PET (SPECT through cerebral blood flow; while PET through glucose metabolism) (Parmar \& Sarkar, 2016). Ciesielski, Hämäläinen, Lesnik, Geller, and Ahlfors (2005) conducted a study to see the change of MEG signal to the patient with the obsessive-compulsive disorder during the phase of encoding, retention, and retrieval when given Delayed Matching-to-Sample working memory Task (DMST). Based on the study, it was found that the pattern of MEG activation experienced an increase in the specific phases. During the encoding phase, the activation increased in the area of the anterior insula and declined in posterior-inferior parietal cortex. At the retention phase, the activation decreased in occipital, parietal, superior temporal sulcus, and dorsolateral prefrontal cortex. Then, at the retrieval phase, there was a significant increase of activation in the right anterior insula to the orbital region and right superior temporal sulcus together with the decrease of activation in the left parietal cortex. Other researchers (Maihöfner et al., 2007) attempted to see the difference in the spontaneous change of MEG between the patient with obsessive-compulsive disorder and average individual. The result showed that patient with obsessive-compulsive disorder experienced a rapid increase in MEG activity over the left hemisphere. The image also showed the increase of activity in the left superior temporal gyrus. It is also recorded a decrease of MEG activity in left dorsolateral prefrontal cortices. The spontaneous change of MEG activity in prefrontal and temporal cortices may be linked to the pathogenesis of obsessivecompulsive disorder.

The Effects of Hormone on the ObsessiveCompulsive Disorder

Obsessive-compulsive disorder is also explained through the hormone mechanism. The experts observed that serotonin (5-HT) together with glutamate neurotransmitter, GABA, and dopamine play an important role in the working mechanism of the orbitofrontal cortex, 
caudate nuclei, and other brain areas. The existence of abnormal activity to one or more neurotransmitters will disturb the working mechanism of brain circuit (Comer, 2010; Pauls et al., 2014). The patient with obsessive-compulsive disorder tends to have a low level of serotonin activity. A number of researchers agreed that in patients with obsessive-compulsive disorder, their serotonin act more as neuromodulator, i.e. a chemical to increase or decrease the core activity for other neurotransmitters (Comer, 2010).

The effect of the hormone on the patient with obsessive-compulsive disorder can be explained through the serotonin hypothesis and the dopamine hypothesis. Serotonin (5-HT) hypothesis is generated from the pharmacological study. In the 1960s, the study showed that clomipramine (antidepressant tricyclic with the nature of strong 5-HT reuptake inhibitor) was able to reduce the symptom of obsessive-compulsive disorder (LopezIbor, as cited in Pauls, Mundo, \& Kennedy, 2002). A number of other research also showed that clomipramine and some Selective Serotonin Reuptake Inhibitors (SSRIs) were proven to be effective antiobsessional agents (Pauls et al., 2002). The experts have attempted to conduct further study about the effect of serotonin. Some studies showed that the patient with obsessive-compulsive disorder experienced serotonin dysfunction (Goodman, McDougle, \& Price, 1992; Insel, Mueller, Alterman, Linnoila, \& Murphy, 1985). Hence, for treating obsessivecompulsive disorder, the drugs have the aim to modify 5-HT neurotransmission in brain regions (Blier \& Montigny, 1998).

Dopamine Hypothesis (DA) focuses on the system and function of dopamine. Some experts stated that a number forms of OCD symptoms etiologically are related to Gilles de la Tourette syndrome (GTS) (Pauls, Alsobrook, \& Goodman, as cited in Pauls et al., 2002). Gilles de la Tourette syndrome or commonly called as Tourette syndrome refers to the neuropsychiatric development disorder characterized by spontaneous and repetitive speeches or motoric movements (more frequently called tics). The patient with obsessivecompulsive disorder with the comorbid tic disorder or GTS usually has a resistance to conventional pharmacotherapy with proserotonergic compounds. On the other side, they tend to be more effective if given the treatment with dopamine (DA) or DA/5-HT blockers (McDougle, as cited in Pauls et al., 2002). Both serotonin and dopamine system will interact with each other extensively - particularly in the basal ganglia (Goodman, Price, \& Woods, as cited in Pauls et al., 2002).

Vulink, Denys, Bus, and Westenberg (2006) studied whether menstruation, pregnancy, and menopause are related to the severity level of obsessive-compulsive disorder symptom. The researchers conducted a study of 350 women as the outpatients of obsessive-compulsive disorder with the instrument of YaleBrown Obsessive-Compulsive Scale. The result of the research showed that $49 \%$ outpatient was indicated to experience the increase of severity of obsessivecompulsive disorder symptom during the pre-menstruation. The increase can be seen from two sides: psychological mechanism and neurobiological mechanism. For some women, menstruation can be seen as a tense event, especially for the patients with high level of fear. Thus, for the patients that are sensitive to the fear, they will feel the large psychological distress during the phase of pre-menstruation. Based on the neurobiological perspective, there is direct 
and indirect evidence that show gonadal steroids affect the severity level of obsessive-compulsive disorder symptom. The direct evidence comes from the oral contraceptives while the indirect evidence is caused by the effect of dopamine function. Studies also showed that estradiol affects the dopamine system through some ways, specifically by increasing dopamine release in caudateputamen and nucleus accumbens, decreasing the dopamine uptake in nucleus accumbens, and shifting striatal D2 dopamine receptors rapidly from highaffinity to low-affinity states (Vulink et al., 2006).

\section{Genetic Factor of Obsessive-Compulsive Disorder}

Genetic factor becomes one issue that is widely discussed when researching about the emergence of a disorder or disease. Many studies on twin siblings and family showed that genetic factor, in fact, plays a quite important role to the emergence of obsessive-compulsive disorder (Chamberlain et al., 2005; Mundo et al., 2006; Pauls, 2001; Pauls et al., 2014). Similar to other mental disorders, obsessive-compulsive disorder can be studied by using the perspective of biological diathesis. This perspective states that there will be a factor of predisposition that will interact with the psychological distress, family environment, and individual learning process in overcoming anxiety (Dorfman \& Walker, 2007).

The study on the identical twin to the patient of obsessive-compulsive disorder has a long history. Research on the identical twin showed that when one child suffers from the obsessive-compulsive disorder, the probability for his or her twin to suffer from obsessive-compulsive disorder is 57\% (Dorfman \& Walker, 2007).
Grootheest, Cath, Beekman, and Boomsma (2005) conducted a study on twin studies since 1929. The result of the study showed that the genetic effect on the obsessivecompulsive disorder to the subject of children reached $45 \%$ to $65 \%$, while the adults reached $27 \%$ to $47 \%$. The level of emergence of obsessive-compulsive disorder will more occur to the monozygotic twin - rather than a dizygotic twin (Chamberlain et al., 2005; Mundo et al., 2006; Pato, Schindler, \& Pato, 2001; Pauls, 2001).

Research to reveal the genetic factor towards the obsessive-compulsive disorder has also been conducted through a direct study on family. The study used the family approach in considering that it is able to map the genetic transfer towards the emergence of disorder or disease. There are two methods used in determining the prevalence to the family, specifically the family history method and the direct interview or family study method. Pauls (2001) in his literature study, found that either in family history method or direct interview, the role of genetics evidently has an important effect on seeing the emergence of obsessivecompulsive disorder to the individual.

Study on genetics can also be done using the segregation analysis - an analysis using the mathematical model to accept or refuse the model of genetic inheritance (to see whether there is or no any effect; if any, to what extent its effect). Based on the studies, it is found a genetic effect on the obsessive-compulsive disorder, and to women, the inheritance process tends to be more compared to the men (Chamberlain et al., 2005; Nestadt et al., 2000). However, the result of regression analysis still needs to be studied further. 
The study of the meta-analysis was conducted by Taylor (2013) to see the molecular genetics to the individual with the obsessive-compulsive disorder. The finding of the meta-analysis indicated that OCD is associated with serotonin-related polymorphisms (5-HTTLPR and HTR2A). Polymorphisms involved in catecholamine modulation (COMT and MAOA) is found only in men. Furthermore, there is no significant trend between two dopamine-related polymorphisms (DAT1 and DRD3) and a glutamate-related polymorphism (rs3087879). The study indicated that OCD is related with multiple genes. Camarena and colleagues (as cited in Chamberlain et al., 2005) also conducted research to examine polymorphisms in serotonin receptor subtypes and the result showed that polymorphism in the 5-HT-1D-beta receptor gene might contribute to the severity level of OCD symptom.

\section{Conclusion}

Neuropsychology research on obsessivecompulsive disorder is important to be further studied. The advanced technology has enabled the existence of developments of neuropsychological research more complex and accurately. Based on the previous research, the individuals with obsessive-compulsive disorder have abnormality in neuroanatomy, abnormality on the working mechanism of the hormone, and the influence of genetic factor. Neuroimaging technique shows the abnormal function in the orbitofrontal cortex and caudate nuclei in the individuals with obsessive-compulsive disorder (Chamberlain et al., 2005; Comer, 2010; Kwon et al., 2009; Saxena \& Rauch, 2000). The study of neuroscience also found that the individuals with obsessivecompulsive disorder have the abnormality in one or more neurotransmitters (serotonin, glutamate, GABA, and dopamine) that will disturb the mechanism of brain circuit work (Comer, 2010; Pauls et al., 2014). Study on genetics showed that the OCD is highly possible affected by the genetic factor (Chamberlain et al., 2005; Mundo et al., 2006; Pauls, 2001; Pauls et al., 2014). The twin sibling; one of which suffers from the OCD have a quite high probability for his or her sibling to suffer from OCD; particularly if occurred in the monozygotic twin.

This article is a literature study based upon the previous studies in terms of the obsessive-compulsive disorder particularly from the neuropsychological perspective. Through the more in-depth understanding of the obsessivecompulsive disorder, it is expected that either family or medical practitioners can be more aware and capable of determining the proper and best handling for the OCD patients.

\section{References}

Abramowitz, J. S., \& Jacoby, R. J. (2015). Obsessive-compulsive and related disorders: A critical review of the new diagnostic class. Annual Review of Clinical Psychology, 11, 8.1-8.22. doi: 10.1146/annurev-clinpsy-032813$\underline{153713}$

American Psychiatric Association. (2000). Diagnostic and Statistical Manual of Mental Disorders Fourth Edition Text Revision. Washington, DC: American Psychiatric Association.

American Psychiatric Association. (2013). Diagnostic and Statistic Manual of Mental Disorders (DSM-5). Airlington, VA: American Psychiatric Association.

Anxiety and Depression Association of 
America (ADAA). (2014). ObsessiveCompulsive Disorder (OCD). Retrieved from https://adaa.org/sites/default/files/OC D_brochure_rev.2014.pdf

Bartha, R., Stein, M. B., Williamson, P. C., Drost, D. J., Neufeld, R. W. J., Carr, T. J., ... Siddiqui, A. R. (1998). A short echo $1 \mathrm{H}$ spectroscopy and volumetric MRI study of the corpus striatum in patients with obsessive-compulsive disorder and comparison subjects. The American Journal of Psychiatry, 155(11), 1584-1591.

Bhakoo, K. K. (2012). N-Acetyl-Aspartate (NAA) metabolism. In I.-Y. Choi \& R. Gruetter (Ed.), Neural metabolism in vivo, advances in neurobiology 4 (pp. 1075-1093). New York: Springer Science+Business Media, LLC 2012. doi: $\underline{10.1007 / 978-1-4614-1788-0}$

Blier, P., \& Montigny, C. De. (1998). Possible serotonergic mechanisms underlying the antidepressant and anti-obsessive-compulsive disorder responses. Society of Biological Psychiatry, 44, 313-323.

Bobes, J., García-Portilla, M., Bascarán, M., Sáiz, P., Bobes-Bascarán, M., \& Bousoño, M. (2007). Quality of life in obsessive-compulsive disorder. In M.S. Ritsner \& A. G. Awad (Eds.), Quality of life impairment in schizophrenia, mood and anxiety disorders (pp. 293-303). Dordrecht: Springer.

Chamberlain, S. R., Blackwell, A. D., Fineberg, N. A., Robbins, T. W., \& Sahakian, B. J. (2005). The neuropsychology of obsessive compulsive disorder: The importance of failures in cognitive and behavioural inhibition as candidate endophenotypic markers. Neuroscience and
Biobehavioral Reviews, 29, 399-419. doi: 10.1016/j.neubiorev.2004.11.006

Ciesielski, K. T., Matti, S. H., Lesnik, P. G., Geller, D. A., \& Ahlfors, S. P. (2005). Increased MEG activation in OCD reflects a compensatory mechanism specific to the phase of a visual working memory task. NeuroImage, 24, 1180-1191. doi: 10.1016/j.neuroimage. 2004.10.018

Comer, R. J. (2010). Abnormal psychology (7th ed.). New York: Worth Publishers.

Dorfman, W. I., \& Walker, L. E. A. (2007). First responder's guide to abnormal psychology: Applications for police, firefighters and rescue personnel. New York: Springer Science_Business Media, LLC.

Durand, V. M., \& Barlow, D. H. (2013). Essentials of abnormal psychology (6th ed.). California: Wadsworth Cengage Learning.

Ebert, D., Speck, O., König, A., Berger, M., Hennig, J., \& Hohagen, F. (1997). 1Hmagnetic resonance spectroscopy in obsessive-compulsive disorder: Evidence for neuronal loss in the cingulate gyrus and the right striatum. Psychiatry Research: Neuroimaging Section, 74, 173-176.

Fineberg, N. A., Saxena, S., Zohar, J., \& Craig, K. J. (2011). Obsessivecompulsive disorder: Boundary Issues. In Eric Hollander, J. Zohar, P. J. Sirovatka, \& D. A. Regier (Eds.), Obsessive-compulsive spectrum disorders: Refining the research agenda for DSM-V (pp. 1-32). Arlington, Virginia: American Psychiatric Association.

Goodman, W. K., McDougle, C. J., \& Price, L. H. (1992). The role of serotonin and dopamine in the pathophysiology of 
obsessive compulsive disorder. International Clinical Psychopharmacology, 7(Suppl. 1), 3538.

Grootheest, D. S. Van, Cath, D. C., Beekman, A. T., \& Boomsma, D. I. (2005). Twin studies on obsessivecompulsive disorder: A review. Twin Research and Human Genetics, 8(5), $450-458$.

Grover, S., \& Dutt, A. (2011). Perceived burden and quality of life of caregivers in obsessive-compulsive disorder. Psychiatry and Clinical Neurosciences, 65, 416-422. doi: 10.1111/j.1440-1819.2011.02240.x

Hirschtritt, M. E., Bloch, M. H., \& Mathews, C. A. (2017). Obsessivecompulsive disorder advances in diagnosis and treatment. JAMA, 317(13), 1358-1367. doi: 10.1001/jama.2017.2200

Hollander, E., Stein, D. J., Kwon, J. H., Rowland, C., Wong, C. M., Broatch, J., \& Himelein, C. (1998). Psychosocial function and economic costs of obsessive-compulsive disorder. CNS Spectrums, 3(5[Suppl 1), 48-58.

Insel, T. R., Mueller, E. A., Alterman, I., Linnoila, M., \& Murphy, D. L. (1985). Obsessive-compulsive disorder and serotonin: Is there a connection? Biological Psychiatry, 20, 1174-1188.

Jahangard, L., Fadaei, V., Sajadi, A., Haghighi, M., Ahmadpanah, M., Matinnia, N., ... Sadeghi, D. (2018). Patients with OCD report lower quality of life after controlling for expert-rated symptoms of depression and anxiety. Psychiatry Research, 260, 318-323. doi: 10.1016/j.psychres. 2017.11.080

Koran, L. M. (2001). Obsessive compulsive disorder and quality of life. In $\mathrm{N}$.
Fineberg, D. Marazziti, \& D. J. Stein (Eds.), Obsessive compulsive disorder: A practical guide (pp. 51-60). London: Martin Dunitz Ltd.

Krzanowska, E., \& Kuleta, M. (2017). From anxiety to compulsivity - a review of changes to OCD classification in DSM-5 and ICD-11. Archives of Psychiatry and Psychotherapy, 3, 7-15. doi: 10.12740/ APP/76150

Kwon, J. S., Jang, J. H., \& Kang, D. (2009). Neuroimaging in obsessive compulsive disorder. Expert Review of Neurotherapeutics, 9(2), 255-269.

Leckman, J. F., Rauch, S. L., \& Mataiz-Cols, D. (2011). Symptom dimensions in obsessive-compulsive disorder: Implications for DSM-5. In Eric Hollander, J. Zohar, P. J. Sirovatka, \& D. A. Regier (Eds.), Obsessivecompulsive spectrum disorders: Refining the research agenda for DSM-V (pp. 117-140). Arlington, Virginia: American Psychiatric Association.

Lucey, J. V., Costa, D. C., Busatto, G., Pilowsky, L. S., Marks, I. M., Ell, P. J., \& Kerwin, R. W. (1997). Caudate regional cerebral blood flow in obsessive-compulsive disorder, panic disorder and healthy controls on single photon emission computerised tomography. Psychiatry Research: Neuroimaging Section, 74, 25-33.

Luxenberg, J. S., Swedo, S. E., Flament, M. F., Friedland, R. P., Rapoport, J., \& Rapoport, S. I. (1988). Neuroanatomical abnormalities in obsessive-compulsive disorder detected with quantitative x-ray computed tomography. The American Journal of Psychiatry, 145(9), 10891093.

Maihöfner, C., Sperling, W., Kaltenhäuser, M., Bleich, S., Zwaan, M. De, 
Wiltfang, J., ... Ropohl, A. (2007). Spontaneous

magnetoencephalographic activity in patients with obsessive-compulsive disorder. Brain Research, 1129, 200205. doi: $10.1016 /$ j.brainres.2006.10.048

Moutaud, B. (2015). DSM-5 and the reconceptualization of obsessivecompulsive disorder, an anthropological perspective from the neuroscience laboratory. In S. Demazeux \& P. Singy (Eds.), The DSM-5 in perspective, history, philosophy and theory of the life sciences 10 (pp. 225-238). Dordrecht: Springer. doi: $\underline{10.1007 / 978-94-017-9765-8}$

Mundo, E., Zanoni, S., \& Altamura, A. C. (2006). Genetic issues in obsessivecompulsive and related disorders. Psychiatric Annals, 36(7), 494-512.

Murray, C. J. L., \& Lopez, A. D. (1996). The global burden of disease: $A$ comprehensive assessment of mortality and disability from diseases, injuries, and risk factors in 1990 and projected to 2020. Boston: Harvard School of Public Health.

Nestadt, G., Lan, T., Samuels, J., Riddle, M., Bienvenu, O. J., Liang, K. Y., ... Shugart, Y. Y. (2000). Complex segregation analysis provides compelling evidence for a major gene underlying obsessive-compulsive disorder and for heterogeneity by sex. The American Journal of Human Genetics, 67, 1611-1616.

Okada, K., Ota, T., Iida, J., Kishimoto, N., \& Kishimoto, T. (2013). Lower prefrontal activity in adults with obsessive-compulsive disorder as measured by near-infrared spectroscopy. Progress in Neuropsychopharmacology $\mathcal{E} \quad$ Biological
Psychiatry, 43, 7-13. doi: 10.1016/ j.pnpbp.2012.11.013

Okasha, A. (2002). Diagnosis of obsessivecompulsive disorder: A review. In M. Maj, N. Sartorius, A. Okasha, \& J. Zohar (Eds.), Obsessive-compulsive disorder. (2nd ed., pp. 1-19). West Sussex: John Wiley \& Sons Ltd.

Ota, T., Iida, J., Sawada, M., Suehiro, Y., Yamamuro, K., Matsuura, H., ... Kishimoto, T. (2013). Reduced prefrontal hemodynamic response in pediatric obsessive-compulsive disorder as measured by near-infrared spectroscopy. Child Psychiatry $\mathcal{E}$ Human Development, 44, 265-277. doi: 10.1007/s10578-012-0323-0

Parmar, A., \& Sarkar, S. (2016). Neuroimaging studies in obsessive compulsive disorder: A narrative review. Indian Journal of Psychological Medicine, 38, 386-394. doi: 10.4103/ $\underline{0253-7176.191395}$

Pato, M. T., Schindler, K. M., \& Pato, C. N. (2001). The genetics of obsessivecompulsive disorder. Current Psychiatry Reports, 3, 163-168.

Pauls, D. L. (2001). The role of genetic factors in OCD. In N. Fineberg, D. Marazziti, \& D. J. Stein (Eds.), Obsessive compulsive disorder: A practical guide (pp. 61-75). London: Martin Dunitz Ltd.

Pauls, D. L., Abramovitch, A., Rauch, S. L., \& Geller, D. A. (2014). Obsessive compulsive disorder: An integrative genetic and neurobiological perspective. Nature Reviews Neuroscience, 15, 410-425. doi: $\underline{10.1038 / \mathrm{nrn} 3746}$

Pauls, D. L., Mundo, E., \& Kennedy, J. L. (2002). The pathophysiology and genetics of obsessive-compulsive disorder. In K. L. Davis, D. Charney, J. T. Coyle, \& C. Nemeroff (Eds.), 
Neuropsychopharmacology: The fifth generation of progress: An official publication of the American College of Neuropsychopharmacology (pp. 16091619). Philadelphia: Lippincott, Williams, \& Wilkins.

Remmerswaal, K. C. P., Batelaan, N. M., Smit, J. H., Oppen, P. Van, \& Balkom, A. J. L. M. Van. (2016). Quality of life and relationship satisfaction of patients with Obsessive Compulsive Disorder. Journal of ObsessiveCompulsive and Related Disorders, 11, 56-62. doi: 10.1016/j.jocrd.2016.08.005

Robinson, D., Wu, H., Munne, R. A., Ashtari, M., Alvir, J. M. J., Lerner, G., ... Bogerts, B. (1995). Reduced caudate nucleus volume in obsessivecompulsive disorder. Archives of General Psychiatry, 52, 393-398.

Sahoo, P., Sethy, R. R., \& Ram, D. (2017). Functional impairment and quality of life in patients with obsessive compulsive disorder. Indian Psychiatric Society, 39(6), 760-765. doi: 10.4103/IJPSYM.IJPSYM 5317

Saxena, S., \& Rauch, S. L. (2000). Functional neuroimaging and the neuroanatomy of obsessivecompulsive disorder. The Psychiatric Clinics of North America, 23(3), 563586.

Schwartzman, C. M., Boisseau, C. L., Eisen, J. L., Rasmussen, S. A., Sibrava, N. J., \& Mancebo, M. C. (2017). Symptom subtype and quality of life in obsessive-compulsive disorder. Psychiatry Research, 249, 307-310. doi: 10.1016/j.psychres.2017.01.025

Sharma, A. (2011). Regional cerebral blood flow. In Kreutzer J. S., Deluca J., \& Caplan B. (Eds.), Encyclopedia of Clinical Neuropsychology (pp. 21352136). New York: Springer. doi:
10.1007/978-0-387-79948-3

Stein, D. J., Kogan, C. S., Atmaca, M., Fineberg, N. A., Fontenelle, L. F., Grant, J. E., ... Reed, G. M. (2016). The classification of obsessive-compulsive and related disorders in the ICD-11. Journal of Affective Disorders, 190, 663674. doi: 10.1016/j.jad.2015.10.061

Stengler-Wenzke, K., Kroll, M., Matschinger, H., \& Angermeyer, M. C. (2006). Subjective quality of life of patients with obsessive - compulsive disorder. Social Psychiatry and Psychiatric Epidemiology, 41, 662-668. doi: $10.1007 / \mathrm{s} 00127-006-0077-8$

Szeszko, P. R., Ardekani, B. A., Ashtari, M., Malhotra, A. K., Robinson, D. G., Bilder, R. M., \& Lim, K. O. (2005). White matter abnormalities in obsessive-compulsive disorder: A diffusion tensor imaging study. Archieves of General Psychiatry, 62, 782-790.

Taylor, S. (2013). Molecular genetics of obsessive-compulsive disorder: A comprehensive meta-analysis of genetic association studies. Molecular Psychiatry, 18, 799-805. doi: 10.1038/ mp.2012.76

Vikas, A., Avasthi, A., \& Sharan, P. (2011). Psychosocial impact of obsessivecompulsive disorder on patients and their caregivers: A comparative study with depressive disorder. International Journal of Social Psychiatry, 57(1), 4556. doi: $\underline{10.1177 / 0020764009347333}$

Vivan, A. D. S., Rodrigues, L., Wendt, G., \& Bicca, M. G. (2013). Quality of life in adolescents with obsessivecompulsive disorder. Revista Brasileira de Psiquiatria, 35, 369-374. doi: 10.1590/1516-4445-2013-1135

Vulink, N. C. C., Denys, D., \& Westenberg, H. G. M. (2006). Female hormones 
affect symptom severity in obsessivecompulsive disorder. International Clinical Psychopharmacology, 21, 171175.

World Health Organization. (2008). The global burden of disease: 2004 update. Geneva: WHO Press.
Wu, M. S., Hamblin, R., Nadeau, J., Simmons, J., Smith, A., Wilson, M., ... Storch, E. A. (2018). Quality of life and burden in caregivers of youth with obsessive-compulsive disorder presenting for intensive treatment. Comprehensive Psychiatry, 80, 46-56. doi: 10.1016/j.comppsych.2017.08.005 